\title{
TAM-ing T cells in the tumor microenvironment: implications for TAM receptor targeting
}

\author{
Marlies J. W. Peeters ${ }^{1}$ (D) Anne Rahbech ${ }^{1} \cdot$ Per thor Straten $^{1,2}$ (D)
}

Received: 8 July 2019 / Accepted: 18 October 2019 / Published online: 29 October 2019

(c) The Author(s) 2019

\begin{abstract}
The TAM receptors-TYRO3, AXL, MERTK - are pleiotropically expressed receptors in both healthy and diseased tissue. A complex of the ligands Protein S (PROS1) or Growth Arrest-Specific 6 (GAS6) with apoptotic phosphatidylserine activates the TAM receptors. Hence, this receptor family is essential for the efferocytosis of apoptotic material by antigen-presenting cells. In addition, TAM receptors are expressed by virtually all cells of the tumor microenvironment. They are also potent oncogenes, frequently overexpressed in cancer and involved in survival and therapy resistance. Due to their pro-oncogenic and immune-inhibitory traits, TAM receptors have emerged as promising targets for cancer therapy. Recently, TAM receptors have been described to function as costimulatory molecules on human T cells. TAM receptors' ambivalent functions on many different cell types therefore make therapeutic targeting not straight-forward. In this review we summarize our current knowledge of the function of TAM receptors in the tumor microenvironment. We place particular focus on TAM receptors and the recently unraveled role of MERTK in activated T cells and potential consequences for anti-tumor immunity.
\end{abstract}

Keywords TAM receptors $\cdot$ MERTK $\cdot$ PROS1 $\cdot$ T lymphocytes $\cdot$ Costimulation $\cdot$ CITIM 2019

$\begin{array}{ll}\text { Abbreviations } & \\ \text { GAS6 } & \text { Growth arrest specific } 6 \\ \text { MERTK } & \text { Mer tyrosine kinase } \\ \text { PROS1 } & \text { Protein S } \\ \text { PtdSer } & \text { Phosphatidylserine } \\ \text { TAM receptors } & \text { TYRO3, AXL, MERTK receptors }\end{array}$

This paper is a Focussed Research Review based on a presentation given at the Sixth International Conference on Cancer Immunotherapy and Immunomonitoring (CITIM 2019), held in Tbilisi, Georgia, 29th April-2nd May 2019. It is part of a series of CITIM 2019 papers in Cancer Immunology, Immunotherapy.

Marlies J. W. Peeters

marlies.peeters@ regionh.dk

1 National Center for Cancer Immune Therapy, Department of Oncology, University Hospital Herlev, Borgmester Ib Juuls Vej 25C, Copenhagen, Denmark

2 Inflammation and Cancer Group, Department of Immunology and Microbiology, University of Copenhagen, Copenhagen, Denmark

\section{Introduction}

After the discovery of the TAM receptors (TYRO3, AXL, MERTK) three decades ago [1], many new functions of this receptor family have been discovered. Their expression is scattered across tissues, both in healthy and diseased, and their functions seem to be as ambivalent. TAM receptors are reported to be functionally expressed in sperm, neurons, platelets and retinal cells [2-5]. In addition, they are frequently overexpressed in cancer, and essentially abundant in innate and adaptive immune cells. Regardless of localization, TAM receptors are activated by their ligands Protein S (PROS1) and Growth Arrest Specific 6 (GAS6) which act as bridging molecules by binding to phosphatidylserine (PtdSer). Subsequently, the PtdSer-GAS6 or PtdSer-PROS1 complex fully activates the receptor. While GAS6 preferentially activates AXL, PROS1 has the highest affinity for MERTK and TYRO3 [6]. When activated, TAM receptor signaling can result in inhibitory or stimulatory responses depending on the cell context.

TAM receptors' ambivalence becomes especially clear in tumor immunology. Their widespread expression in both cancer cells and various tumor-infiltrating immune cells can make conclusions indecisive. In this review, we will discuss the function of TYRO3, AXL and MERTK on all 
cells in the tumor micro-environment, with a special focus on $\mathrm{T}$ cells. The recently uncovered function of MERTK on activated $T$ cells could have an important impact on antitumor immunity.

\section{TAM receptors in the tumor microenvironment}

\section{Cancer}

TAM receptors are reported to be overexpressed in both solid and hematological malignancies, and high expression of the TAM receptors has been associated with poor patient survival in a variety of cancers [7, 8]. Oncogenic TAM receptor signaling results in increased proliferation, cell survival and metastasis (reviewed in [7]). Many tumors express not only the receptors, but also the ligands PROS1 and GAS6 [9, 10]. In combination with the abundant presence of apoptotic PtdSer [11], cancer cells are capable of TAM receptor auto-signaling. This subsequently results in the activation of various downstream pathways, including ERK, MAPK, AKT and others [12, 13]. Interestingly, TAM receptors have been implicated in therapy resistance to MAPK, PI3 K and EGFR inhibitors [13]. Mechanistically, a study from Kotenko et al. showed that TAM receptor expression leads to upregulation of PD-L1, possibly contributing to therapy resistance [14].

As a result, TAM receptors seem an attractive target for cancer therapy, not in the least to overcome therapy resistance. Many small molecule inhibitors have been developed, which are usually reactive to all three TAM receptors [15]. Currently, AXL inhibitors are in clinical testing for NSCLC and pan-TAM inhibitors are in clinical testing for the treatment of metastasized solid tumors $[8,16]$. In addition, many inhibitors are currently in the preclinical phase where they show anti-tumor activity (reviewed in [8]). Finally, MERTK is frequently overexpressed in leukemias, including T-ALL $[15,17]$. Mouse studies show promising results where MERTK inhibition favors tumor regression [18]. In conclusion, TAM receptor targeting is a promising strategy for cancer therapy. However, since many other cell types express TAM receptors, inhibition of this integral receptor should be considered in the wider context of tumor-associated immune responses. It will be interesting to see how TAM receptor inhibition for cancer treatment develops, and caution might be warranted due to adverse immunological side effects.

\section{Antigen-presenting cells}

Efferocytosis is the process of apoptotic cell clearance by antigen-presenting cells (APCs), including macrophages and dendritic cells (DCs). This is an essential process for tissue homeostasis. Due to regular cellular turnover, billions of apoptotic cells are removed by efferocytosis every day in the human body [19]. All three TAM receptors have essential functions in efferocytosis in APCs, which has been reviewed in detail by Rothlin and colleagues [20]. In short, TAM receptors in APCs are essential for efferocytosis and subsequent immune-suppressive signals. TAM receptor knockout mice have significant defects in the efferocytosis of apoptotic cells by APCs [21]. As a result, these mice show hyperactivation of APCs and subsequent autoimmunity.

TYRO3, AXL, and MERTK have distinct roles on APCs. Seitz et al. reported MERTK to be the main receptor for efferocytosis on macrophages, whereas AXL and TYRO3 were most essential for DCs [22]. In addition, Zagorska et al. showed MERTK to be a tolerogenic receptor in macrophages and during immunosuppression [23]. Correspondingly, they reported AXL to be an inflammatory response receptor on DCs, induced by proinflammatory stimuli. The molecular basis of TAM receptor signalling in APCs has been elucidated and functions mainly via downstream SOCS ubiquitin ligases and inhibition of Toll-like receptor signalling (reviewed in detail by Rothlin and colleagues [20]).

\section{NK and NKT cells}

NK cells are important components of the innate immune system, as they provide rapid responses to both pathogens and tumors. TAM receptors play an important role in the differentiation of these cells. Caraux et al. showed that all three TAM receptors were expressed by maturing NK cells in mice [24]. This TAM receptor expression by NK cells was deemed essential for mouse NK cell maturation and subsequent expression of both inhibitory and activating receptors. It was also reported that AXL was essential for human NK cell development from hematopoietic progenitor cells [25]. The TAM receptors reportedly regulate NK cell development via IL-15, c-kit and T-BET [24, 25]. Furthermore, Paolino et al. reported that ubiquitination of the TAM receptors on mouse NK cells inhibited their proliferation and cytotoxicity in a tumor metastasis model [26].

Finally, MERTK has been reported to be functionally expressed by mouse NKT cells [27]. Genetic deletion of MERTK resulted in impaired cytokine secretion after antigen-induced activation. This was due to an intrinsic NKT cell defect, as the source of antigen-presenting cells (wild-type or MERTK-deficient) did not alter the impaired MERTK-deficient NKT cell response [27]. Taken together, all studies point toward an essential role for the TAM receptors in the functional maturation and cytotoxicity of $\mathrm{NK}(\mathrm{T})$ cells. 


\section{B cells}

In 2008, Shao et al. reported MERTK to be functionally expressed by wildtype mouse B cells. In their study, B cells upregulated MERTK upon chronic GvHD, while MERTKdeficient mice were protected against GvHD [28]. A few years later, the same group showed that upon MERTK depletion in mouse B cells, B cells decreased their antibody production and subsequent $\mathrm{T}$ cell activation [29]. Consistent with a stimulatory role for TAM receptors in B cells, both AXL and TYRO3 are reported to be overexpressed in B cell chronic lymphocytic leukemia patient samples [30, 31]. Correspondingly, AXL inhibition decreased B leukemia cell survival in vitro [30]. In conclusion, only a handful of researchers have studied the function of TAM receptors on $\mathrm{B}$ cells. The overall hypothesis links TAM receptor signaling to healthy B cell responses. Hence, dysregulation of TAM receptor signaling could lead to aberrant B cell proliferation and leukemia, although more research is needed.

\section{Platelets}

TAM receptors on platelets have been well studied, and all three TAM receptors are expressed by both mouse and human platelets [2, 32, 33]. Various combinations of single, double, and triple TAM receptor knockouts have shown that all three TAM receptors are individually essential for normal platelet function [33]. Deletion of one of the TAM receptors resulted in mild dysfunctional platelets. Deletion of any two of the three TAM receptors did not affect platelet counts, but impaired hemostasis and platelet function. Lastly, absence of all three TAM receptors resulted in thrombocytopenia, severely impaired hemostasis and platelet function, and defective megakaryocytopoiesis [33]. In this regard, smallmolecule MERTK-inhibition decreased mouse platelet activation and subsequent thrombosis [34]. Taken together, TAM receptor expression by platelets is essential for regular platelet function in both human and mouse.

\section{TAM receptors in T cells}

\section{TAM receptor and ligand expression by T cells}

T cells were long believed to be negative for TAM receptors. For the ligands, however, results have consistently showed expression by activated T cells. In 1997, it was shown for the first time that PROS1 expression was induced in mouse lymphocytes (both $\mathrm{CD} 4^{+}$and $\mathrm{CD} 8^{+}$) upon TCR activation [35]. IL-4 addition further upregulated PROS1 expression and subsequent secretion. Almost two decades later, PROS1 expression in TCR-activated $\mathrm{CD} 4^{+} \mathrm{T}$ cells was confirmed by Carrera Silva et al. in both mouse and human [36].
Subsequently, Chan et al. showed that PROS1 expression in mouse $\mathrm{CD}^{+}{ }^{+} \mathrm{T}$ cells was limited to the $\mathrm{TH} 2$ subset, and that PROS1 expression was dependent on IL-4 [37]. Regarding $\mathrm{CD}^{+} \mathrm{T}$ cells, our group recently verified PROS1 expression by human $\mathrm{CD}^{+}{ }^{+} \mathrm{T}$ cells, as they expressed PROS1 upon TCR stimulation from day 2 onwards [38]. A more detailed overview of PROS1 expression in lymphocytes is found in Table 1. In all studies, resting $\mathrm{T}$ cells remained negative. Taken together, these studies prove that the TAM receptor ligand PROS 1 is expressed and secreted by TCR-activated $\mathrm{T}$ cells. Interestingly, PROS1 was surface-bound in both ours and Carrera Silva's study. This indicates that PROS1 is bound to either PtdSer or the TAM receptors, which could both be expressed by T cells. As for the other TAM receptor ligand GAS6, no expression by T cells has been reported.

In the early 2000s, two studies reported that T cells did not express the TAM receptors. Both studies reported no MERTK expression after two-day activation of mouse splenocytes with $\alpha \mathrm{CD} 3$, or two-day activation of human T cells with PHA/PMA [17, 27]. In 2014, a study which reported increased MERTK and TYRO3 expression on $\mathrm{CD} 4^{+} \mathrm{T}$ cells from SLE patients went rather unnoticed [39]. The following year, Cabezon et al. convincingly showed that TCR-activated human $\mathrm{CD} 4^{+} \mathrm{T}$ cells expressed MERTK from day 3 onwards [40]. In addition, it was reported that murine $\mathrm{CD}^{+}$regulatory T cells expressed both AXL and MERTK, without in vitro or in vivo stimulation [41]. Regarding $\mathrm{CD}^{+} \mathrm{T}$ cells, Yokoyama et al. suggested that (mouse) $\mathrm{CD} 45^{+}$TILs could be responsible for increased MERTK levels in the tumormicroenvironment [42]. Finally, our group recently verified TAM receptor expression on human $\mathrm{CD}^{+}$and $\mathrm{CD} 8^{+}$ $\mathrm{T}$ cells. We demonstrated on three different levels (RNA, protein, surface expression) that MERTK was expressed on TCR-activated human $\mathrm{CD} 8^{+} \mathrm{T}$ cells and $\mathrm{CD}^{+} \mathrm{T}$ cells [38]. In addition, we did not detect AXL and only a low amount of TYRO3.

The discrepancy of all later reports with the two earliest studies could be explained by the chosen species, timepoint, or stimulation method (a definitive overview is found in Table 1). Based on these studies, whether mouse $T$ cells do or do not express any TAM receptor is until now not definitively proven. In humans, TAM receptor expression is better studied, especially regarding MERTK. Both Cabezon and our study showed that MERTK expression is only induced by TCR-mediated (e.g. via CD3 or peptide) activation and only detectable after 2 or 3 days [38, 40]. This could explain why Graham et al. found human T cells negative, as these were stimulated with non-TCR-specific PHA/PMA and the experiment did not go beyond $48 \mathrm{~h}$ [17].

According to our knowledge, only four studies have been published on MERTK expression on human T cells in the past 25 years (Table 1). The three most recent studies consistently found a varying amount and subset of $\mathrm{T}$ cells 
Table 1 Evidence for TAM receptor and ligand expression by T lymphocytes

\begin{tabular}{|c|c|c|c|c|c|}
\hline Cell type & Stimulant & $\begin{array}{l}\text { TAM receptor/ligand expres- } \\
\text { sion }\end{array}$ & Additional findings & Species & Reference \\
\hline $\begin{array}{l}\mathrm{CD}^{+} \mathrm{T} \text { cells from lymph } \\
\text { node }\end{array}$ & $\alpha \mathrm{CD} 3 \pm \mathrm{IL}-4,24 \mathrm{~h}$ & $\mathrm{PROS}^{+}$ & $\begin{array}{l}\text { Resting } \mathrm{CD}^{+} \text {and } \mathrm{CD} 8^{+} \mathrm{T} \\
\text { cells were negative. IL-4 } \\
\text { increased TCR-induced } \\
\text { PROS1 expression. }\end{array}$ & Murine & {$[35]$} \\
\hline $\begin{array}{l}\mathrm{CD}^{+} \mathrm{T} \text { cells from perito- } \\
\text { neum }\end{array}$ & $\begin{array}{l}\text { In vivo antigen activation by } \\
\text { thymoma cancer cells }\end{array}$ & PROS $1^{+}$ & - & Murine & {$[35]$} \\
\hline $\mathrm{CD}^{+} \mathrm{T}$ cells from PBMCs & PHA/PMA, up to $48 \mathrm{~h}$ & MERTK- & $\begin{array}{l}\text { Directly ex vivo thymocytes } \\
\text { negative for MERTK }\end{array}$ & Human & [17] \\
\hline $\mathrm{T}$ cells from splenocytes & $\alpha \mathrm{CD} 3$, up to $48 \mathrm{~h}$ & MERTK- & - & Murine & [27] \\
\hline OT-II CD4 ${ }^{+} \mathrm{T}$ cells & OVA-DCs, $24 \mathrm{~h}$ & $\mathrm{PROS}^{+}$ & - & Murine & {$[36]$} \\
\hline $\begin{array}{l}\text { Naïve } \mathrm{CD} 4^{+} \mathrm{T} \text { cells from } \\
\text { PBMCs }\end{array}$ & $\alpha \mathrm{CD} 3 / \mathrm{CD} 28$, up to 6 days & $\mathrm{PROS}^{+}$ & $\begin{array}{l}\text { Positive from day } 3 \text { onwards. } \\
\text { Conserved in reactive } \\
\text { lymph nodes (human) }\end{array}$ & Human & {$[36]$} \\
\hline $\begin{array}{l}\text { Naïve } \mathrm{CD}^{+} \mathrm{T} \text { cells from } \\
\text { PBMCs }\end{array}$ & $\alpha \mathrm{CD} 3 / \mathrm{CD} 28$, up to 7 days & MERTK $^{+}$ & Positive from day 3 onwards & Human & [40] \\
\hline $\begin{array}{l}\mathrm{CD} 4^{+} \mathrm{CD} 25^{+} \text {Tregs from } \\
\text { splenocytes }\end{array}$ & $\begin{array}{l}\text { Directly ex vivo, no in vitro } \\
\text { stimulation }\end{array}$ & $\mathrm{AXL}^{+} \mathrm{MERTK}^{+}$ & $\begin{array}{l}\mathrm{CD} 4{ }^{+} \mathrm{CD} 25-\text { cells were } \\
\text { negative }\end{array}$ & Murine & {$[41]$} \\
\hline TH2 from splenocytes & $\begin{array}{l}\alpha \mathrm{CD} 3 / \mathrm{CD} 28 \text { and } \mathrm{TH} 2 \text { polari- } \\
\text { zation, } 5 \text { days }\end{array}$ & PROS $^{+}$ & $\begin{array}{l}\text { IL-4 dependent. TH1 and } \\
\text { TH17 were negative }\end{array}$ & Murine & [37] \\
\hline $\mathrm{CD}_{4} 5^{+} \mathrm{TILs}$ & $\begin{array}{l}\text { Directly ex vivo, no in vitro } \\
\text { stimulation }\end{array}$ & MERTK $^{+}$ & $\begin{array}{l}\text { Gene expression from } \\
\text { CD } 45^{+} \text {TILs in the tumor } \\
\text { micro-environment }\end{array}$ & Murine & {$[42]$} \\
\hline $\begin{array}{l}\mathrm{CD} 4^{+} \mathrm{CD} 8^{+} \mathrm{T} \text { cells from } \\
\text { PBMCs, healthy donors } \\
\text { and SLE patients }\end{array}$ & $\begin{array}{l}\text { Directly ex vivo, no in vitro } \\
\text { stimulation }\end{array}$ & MERTK $-/^{+}$, TYRO3 $-/^{+}$ & $\begin{array}{l}\text { Ex vivo, unstimulated T cells } \\
\text { from healthy donors were } \\
\text { negative for MERTK and } \\
\text { TYRO3. CD } 4^{+} \text {T cells } \\
\text { from SLE patients had } \\
\text { increased MERTK and } \\
\text { TYRO3 expression. CD8 }{ }^{+} \\
\text {remained negative. }\end{array}$ & Human & [39] \\
\hline $\begin{array}{l}\mathrm{CD}^{+} \mathrm{T} \text { cells from PBMCs, } \\
\mathrm{CD}^{+} \mathrm{T} \text { cells from PBMCs }\end{array}$ & $\begin{array}{l}\alpha \mathrm{CD} 3 / \mathrm{CD} 28 \text { up to } 4 \text { days, } \\
\text { CMV/EBV/flu peptide } \\
\text { stimulation for } 48 \mathrm{~h}\end{array}$ & $\begin{array}{l}\text { PROS1 }^{+}, \mathrm{MERTK}^{+}, \\
\text {TYRO3-/ } \\
\text { AXL- }\end{array}$ & Positive from day 2 onwards & Human & {$[38]$} \\
\hline
\end{tabular}

SLE systemic lupus erythematosus, EVB Epstein-Barr virus

MERTK-positive. Combined with the independent and varying investigation methods used, these are compelling arguments for MERTK expression on primary $\mathrm{T}$ cells. Taken together, we conclude that TCR-activation leads to MERTK expression on both $\mathrm{CD}^{+}{ }^{+}$and $\mathrm{CD}^{+}$human $\mathrm{T}$ cells. Combined with the T cell's expression of PROS1, it becomes necessary to elucidate in what functional capacity the TAM receptors and ligands are expressed by $\mathrm{T}$ cells.

\section{TAM receptor function in T cells}

Shortly after PROS1 was described to be expressed by mouse T cells, PROS1's function on T cells was studied by the same group. Their study initially suggested that receptors for PROS1 transduced proliferative signals [43]. As the function and expression pattern of the TAM receptors was at that moment unknown, they attributed any positive or negative role to the anti-coagulant functions of PROS1 [43]. Their initial suggestion, however, that an Fc-TAM receptor competed with T cells for the ligand PROS1, proved to be correct two decades later. In this later study, Cabezon et al. added FcMERTK to $\mathrm{CD}^{+}{ }^{+} \mathrm{T}$ cells. Subsequent PROS1 ligand depletion resulted in inhibition of $\mathrm{T}$ cell proliferation and activation [40]. Accordingly, adding exogenous PROS1 increased cytokine secretion and proliferation. This corresponds with our data on $\mathrm{CD}^{+} \mathrm{T}$ cells, where PROS1 positively regulated proliferation and cytokine secretion. We validated PROS1 signal transduction through MERTK using MERTK-inhibitors and knockdown of MERTK on $\mathrm{CD}^{+} \mathrm{T}$ cells [38]. As for GAS6, it has been reported that exogenous GAS6 could increase the suppressive properties of mouse $\mathrm{CD} 4^{+}$regulatory T cells via T cell-expressed AXL [41]. Furthermore, Keating et al. overexpressed MERTK in mouse T lymphocytes [44]. Their results showed that dysregulation of MERTK on T cells caused $\mathrm{T}$ cell leukemia due to uncontrolled division and proliferation. This highlights MERTK as a stimulatory T-cell 
molecule which, when dysregulated, results in disproportionate stimulatory and proliferative signals.

Since $\mathrm{T}$ cells have been believed not to express MERTK, previous results might need to be re-interpreted. To this end, it was previously shown that treatment of wildtype immunocompetent mice with MERTK-inhibitors decreased PD-1 expression on T cells [45]. PD-1 is solely expressed by previously activated T cells, is dependent on TCR signal strength and avidity, and is an identifying marker for tumor-reactive T cells [46]. T cells lacking PD-1 upon MERTK-inhibition are therefore likely to be less activated, non-tumor-reactive and correspondingly, less likely to respond to PD-1 immunotherapy. In agreement, we have shown with a MERTKspecific inhibitor that MERTK inhibition decreased T cell proliferation and cytokine secretion [38].

Finally, both Cabezon et al.'s and our study have indications that MERTK could regulate the T cell memory response. As MERTK seems to be a 'late' costimulatory molecule on T cells (only detectable from day 2-3 up to day 7-and possibly longer-after TCR activation), this is a tempting explanation. It will be exciting to see what future research uncovers. All in all, it becomes increasingly clear that the PROS1-MERTK axis has a functional impact on (human) $\mathrm{T}$ cells. Contrary to previous dogma, T cells do express TAM receptors and most importantly, MERTK seems a strong costimulatory receptor upon $\mathrm{T}$ cell activation (Fig. 1). This opens up exciting new

\section{A}

(1) Single-expression model
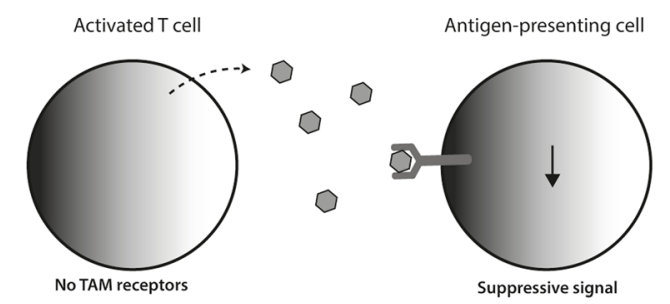

(2) Double-expression model
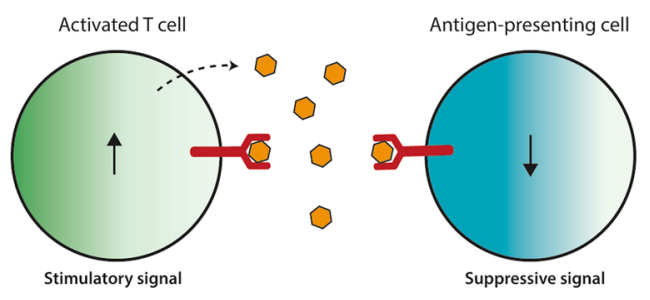

Fig. 1 Consequences of TAM receptor signaling on T cells and competing cells. a Previously, T cells were thought to express PROS1, but not TAM receptors. PROS1 secretion by T cells subsequently resulted in a negative feedback loop to the APC. In the double-expression model, T-cell secreted PROS1 serves as an auto-stimulatory signal for the $\mathrm{T}$ cell and an inhibitory signal for the APC. b Activated T cells express PROS1, TAM receptors, and PtdSer. When the T cell encounters a TAM receptor negative cell, PROS1 will activate MERTK on areas in research for the TAM receptor field, as T cells are now added to the long list of TAM receptor-expressing cells. As availability of the ligands in vivo is not limitless, it will be important to pinpoint the net effect of TAM receptor signaling on the various immune subsets and cancer cells.

\section{TAM receptor targeting in the tumor microenvironment}

As both cancer cells and immune cells express TAM receptors in various functional outputs, predicting the outcome of TAM receptor targeting in vivo is not straightforward. Hence, it is surprising that very few studies have been done regarding the immunological consequences of TAM receptor inhibition. Most of the studies have been performed in immunocompromised mice (reviewed in [8]). Only recently, the immunological consequences of TAM receptor inhibition for cancer treatment have gained more experimental attention [47]. These studies will become increasingly important as combination therapies with, e.g. immunotherapy are on the rise. With the many cell types expressing TAM receptors, the intended effect is not always trivial to predict. As a result, TAM receptor inhibitors for cancer therapy could result in unexpected effects in immunocompetent in vivo studies. For example, ablation of AXL and

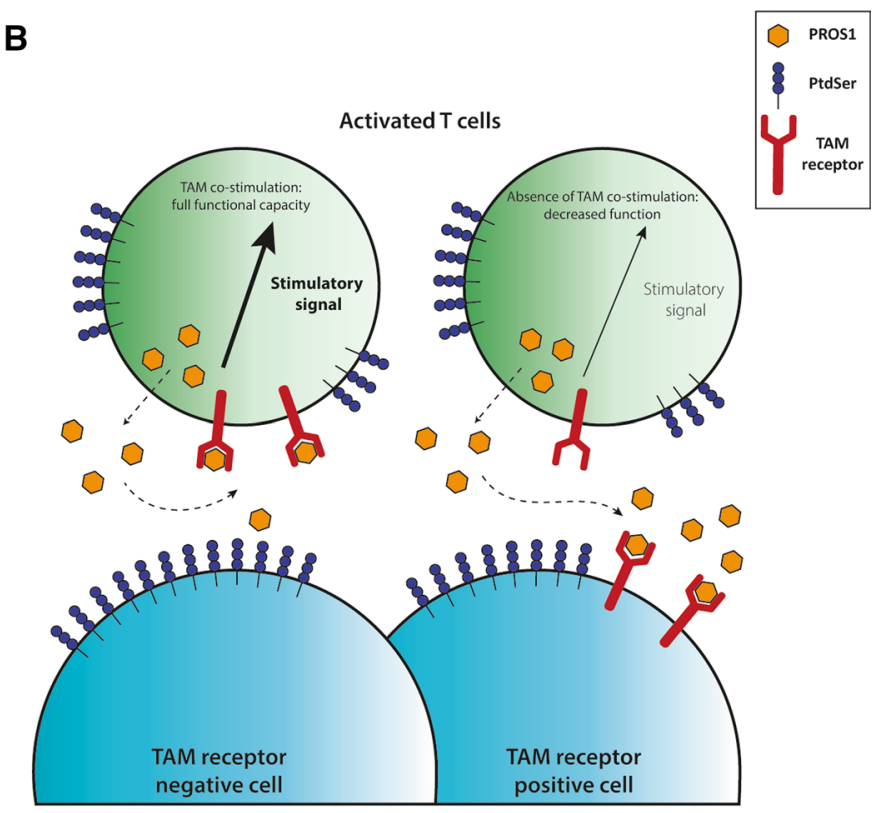

the T cell. When the T cell encounters another TAM receptor positive cell, PROS1 will be competed for, as APCs and cancer cells express high amounts of TAM receptors. T cell-produced PROS1 will subsequently activate the other TAM receptor-positive cell (APC, cancer cell) and T cells will lose the PROS1-MERTK costimulatory signal. PROS1 Protein S, PtdSer phosphatidylserine, TAM receptor TYRO3, AXL, MERTK receptor family 
MERTK resulted in increased incidence of inflammatory colon cancer in mice [48]. In another model, TAM receptors on NK cells were found to positively regulate metastasis. Subsequent TAM receptor inhibition on NK cells, but not cancer cells, could decrease tumor burden [26]. Yet another study found that a pan-TAM receptor inhibitor for cancer treatment was only effective in immunocompetent mice, confirming the mode of action solely via effects on innate immune cells and not on the tumor [42].

Due to the TAM receptor inhibitors' strong effect on APCs, TAM receptor inhibitors may well be interesting for their innate immunological effect, instead of their direct effect on cancer cells [47]. For AXL-specific or TYRO3-specific inhibitors, the desired anti-tumor immunological effect could be relatively easy to reach as these receptors dominantly function as immuneinhibitory receptors on APCs. AXL is implicated in therapy resistance and epithelial-mesenchymal transition, acts as a suppressive molecule on innate immune cells, and is absent as a costimulatory molecule on $\mathrm{T}$ cells $[38,47]$. Therefore, targeting AXL using inhibitors is a very promising strategy through both direct effects on cancer cells, and indirect effects via activation of APCs and a subsequent anti-tumor immune response.

MERTK, however, has now emerged as a T-cell costimulatory molecule (Fig. 1). A previous study has shown that PROS1 ligand depletion by DCs will decrease T cell functionality [40]. This could be similar for the interaction of $\mathrm{T}$ cells with cancer cells. We have shown that low doses of PROS1 favor the tumor cells, by co-culturing MERTKexpressing T cells with high MERTK-expressing cancer cells [38]. Once saturating doses of PROS1 were reachedenough for both the T cells and the cancer cells-this effect was reversed as ligand competition was abrogated. In addition, MERTK-activation by exogenous PROS1 supplementation increased cytotoxicity of tumor infiltrating lymphocytes against autologous melanoma cells, despite high level of MERTK expression by the autologous tumor cell line.

Collectively, this leads us to believe that high TAM receptor-expressing cells (whether APCs or cancer cells) can compete with MERTK-expressing T cells for the PROS1 ligand in the tumor microenvironment or periphery (Fig. 1). MERTK inhibition subsequently decreases T cell functionality, whether through simple absence of the ligand or by direct inhibition. Collectively, this underscores the pitfalls of MERTK-inhibitors as cancer treatment, specifically in combination with $\mathrm{T}$ cell-based immunotherapy.

\section{Conclusion and perspectives}

TAM receptors are potent oncogenes as underscored by numerous studies. Their overexpression plays an important role in therapy resistance, which prompted the development of TAM receptor inhibitors. While these show promising results in immunocompromised mice, studies in immune competent animals will be essential. As broad immunosuppressive signals in innate cells, TAM receptor inhibition could unleash an innate-driven anti-tumor immune response. Correspondingly, side effects could be severe. Triple TAM receptor knockout mice have massive lymphoproliferation, lupus-like symptoms, sterility, platelet dysfunction and inflammatory brain damage, among other symptoms [21, 49]. Blocking all three TAM receptors using inhibitors, should therefore be tightly controlled-if used at all-to prevent serious side effects. Loss or inhibition of only one of the TAM receptors seems more feasible.

As discussed earlier in this review, MERTK-specific inhibition could have ambiguous effects. TAM receptor inhibition has been suggested to be combined with T cellbased immunotherapy (e.g. anti-PD-1). Targeting MERTK would negatively affect $\mathrm{T}$ cell functionality, rendering PD-1 therapy counter-productive. It is tempting to speculate that activating MERTK on T cells would result in better T-cell stimulation and thus therapeutic outcomes. Direct administration of MERTK-agonists in vivo is not feasible, due to its overexpression in cancer. With the development of bior tri-specific antibodies and the improvements of CAR-, TCR-, or TIL-based T cell therapies, however, elucidating the mechanism of MERTK on T cells will be of great interest. Nevertheless, there are still many open questions. Until this date, it is unknown whether mouse $\mathrm{T}$ cells are truly negative for TAM receptor expression. Secondly, the mechanism of MERTK-mediated costimulation remains to be studied. Finally, definitive proof of MERTK's involvement in generation of $\mathrm{T}$ cell memory and differentiation is yet to be unraveled. These questions open an exciting new era in TAM receptor research.

In conclusion, TAM receptors are attractive targets for cancer therapy, not in the least because of their suppressive actions in innate cells. Due to their widespread expression on many cells, including essential immune cells, the net results might not be as expected. We excitingly await future studies which determine if oncogenic TAM signaling in cancer cells, inhibitory TAM signaling in innate cells, or costimulatory TAM signaling in cytotoxic T cells, will tip the scale towards or against anti-tumor immunity.

Acknowledgements The authors would like to thank Richard M. Powell (National Center for Cancer Immune Therapy, Copenhagen, Denmark) for critically reading the manuscript.

Author contributions MJWP, AR performed the literature research, wrote the paper, and designed the figure. PtS critically revised the manuscript.

Funding This study is partially supported by the Training Network for the Immunotherapy of Cancer (IMMUTRAIN, H2020, grant no. 
641549 to Marlies J.W. Peeters and Per thor Straten), funded by the European Union.

\section{Compliance with ethical standards}

Conflict of interest Per thor Straten and Marlies J.W. Peeters are authors on a pending European patent 18168195.8 pertaining the use of MERTK in adoptive T cell therapy. Anne Rahbech declares no competing interests.

Open Access This article is distributed under the terms of the Creative Commons Attribution 4.0 International License (http://creativeco mmons.org/licenses/by/4.0/), which permits unrestricted use, distribution, and reproduction in any medium, provided you give appropriate credit to the original author(s) and the source, provide a link to the Creative Commons license, and indicate if changes were made.

\section{References}

1. Lai C, Lemke G (1991) An extended family of protein-tyrosine kinase genes differentially expressed in the vertebrate nervous system. Neuron 6(5):691-704

2. Gould WR, Baxi SM, Schroeder R, Peng YW, Leadley RJ, Peterson JT, Perrin LA (2005) Gas6 receptors Axl, Sky and Mer enhance platelet activation and regulate thrombotic responses. J Thromb Haemost 3(4):733-741. https://doi.org/10.111 1/j.1538-7836.2005.01186.x

3. Ji R, Meng L, Jiang X, Cvm NK, Ding J, Li Q, Lu Q (2014) TAM receptors support neural stem cell survival, proliferation and neuronal differentiation. PLoS One 9(12):e115140. https:// doi.org/10.1371/journal.pone.0115140

4. Lu Q, Gore M, Zhang Q, Camenisch T, Boast S, Casagranda F, Lai C, Skinner MK, Klein R, Matsushima GK, Earp HS, Goff SP, Lemke G (1999) Tyro-3 family receptors are essential regulators of mammalian spermatogenesis. Nature 398(6729):723-728. https ://doi.org/10.1038/19554

5. Prasad D, Rothlin CV, Burrola P, Burstyn-Cohen T, Lu Q, Garcia de Frutos P, Lemke G (2006) TAM receptor function in the retinal pigment epithelium. Mol Cell Neurosci 33(1):96-108. https://doi. org/10.1016/j.mcn.2006.06.011

6. Tsou WI, Nguyen KQ, Calarese DA, Garforth SJ, Antes AL, Smirnov SV, Almo SC, Birge RB, Kotenko SV (2014) Receptor tyrosine kinases, TYRO3, AXL, and MER, demonstrate distinct patterns and complex regulation of ligand-induced activation. J Biol Chem 289(37):25750-25763. https://doi.org/10.1074/jbc. M114.569020

7. Graham DK, DeRyckere D, Davies KD, Earp HS (2014) The TAM family: phosphatidylserine sensing receptor tyrosine kinases gone awry in cancer. Nat Rev Cancer 14(12):769-785. https://doi. org/10.1038/nrc3847

8. Paolino M, Penninger JM (2016) The role of TAM family receptors in immune cell function: implications for cancer therapy. Cancers (Basel). https://doi.org/10.3390/cancers8100097

9. Ubil E, Caskey L, Holtzhausen A, Hunter D, Story C, Earp HS (2018) Tumor-secreted Pros1 inhibits macrophage M1 polarization to reduce antitumor immune response. J Clin Invest 128(6):2356-2369. https://doi.org/10.1172/JCI97354

10. Wu G, Ma Z, Cheng Y, Hu W, Deng C, Jiang S, Li T, Chen F, Yang Y (2018) Targeting Gas6/TAM in cancer cells and tumor microenvironment. Mol Cancer 17(1):20. https://doi.org/10.1186/ s12943-018-0769-1

11. Birge RB, Boeltz S, Kumar S, Carlson J, Wanderley J, Calianese D, Barcinski M, Brekken RA, Huang X, Hutchins JT, Freimark
B, Empig C, Mercer J, Schroit AJ, Schett G, Herrmann M (2016) Phosphatidylserine is a global immunosuppressive signal in efferocytosis, infectious disease, and cancer. Cell Death Differ 23(6):962-978. https://doi.org/10.1038/cdd.2016.11

12. Jiang Y, Zhang Y, Leung JY, Fan C, Popov KI, Su S, Qian J, Wang X, Holtzhausen A, Ubil E, Xiang Y, Davis I, Dokholyan NV, Wu G, Perou CM, Kim WY, Earp HS, Liu P (2019) MERTK mediated novel site Akt phosphorylation alleviates SAV1 suppression. Nat Commun 10(1):1515. https://doi. org/10.1038/s41467-019-09233-7

13. Vouri M, Hafizi S (2017) TAM receptor tyrosine kinases in cancer drug resistance. Cancer Res 77(11):2775-2778. https:// doi.org/10.1158/0008-5472.CAN-16-2675

14. Kasikara C, Kumar S, Kimani S, Tsou WI, Geng K, Davra V, Sriram G, Devoe C, Nguyen KN, Antes A, Krantz A, Rymarczyk G, Wilczynski A, Empig C, Freimark B, Gray M, Schlunegger K, Hutchins J, Kotenko SV, Birge RB (2017) Phosphatidylserine sensing by TAM receptors regulates AKT-dependent chemoresistance and PD-L1 expression. Mol Cancer Res 15(6):753-764. https://doi.org/10.1158/1541-7786.MCR-16-0350

15. Huey MG, Minson KA, Earp HS, DeRyckere D, Graham DK (2016) Targeting the TAM receptors in leukemia. Cancers (Basel). https://doi.org/10.3390/cancers8110101

16. Myers SH, Brunton VG, Unciti-Broceta A (2016) AXL inhibitors in cancer: a medicinal chemistry perspective. J Med Chem 59(8):3593-3608. https://doi.org/10.1021/acs.jmedchem.5b012 73

17. Graham DK, Salzberg DB, Kurtzberg J, Sather S, Matsushima GK, Keating AK, Liang X, Lovell MA, Williams SA, Dawson TL, Schell MJ, Anwar AA, Snodgrass HR, Earp HS (2006) Ectopic expression of the proto-oncogene Mer in pediatric T-cell acute lymphoblastic leukemia. Clin Cancer Res 12(9):2662-2669. https ://doi.org/10.1158/1078-0432.CCR-05-2208

18. DeRyckere D, Lee-Sherick AB, Huey MG, Hill AA, Tyner JW, Jacobsen KM, Page LS, Kirkpatrick GG, Eryildiz F, Montgomery SA, Zhang W, Wang X, Frye SV, Earp HS, Graham DK (2017) UNC2025, a MERTK small-molecule inhibitor, is therapeutically effective alone and in combination with methotrexate in leukemia models. Clin Cancer Res 23(6):1481-1492. https://doi. org/10.1158/1078-0432.CCR-16-1330

19. Morioka S, Maueroder C, Ravichandran KS (2019) Living on the edge: efferocytosis at the interface of homeostasis and pathology. Immunity 50(5):1149-1162. https://doi.org/10.1016/j.immun i.2019.04.018

20. Rothlin CV, Carrera-Silva EA, Bosurgi L, Ghosh S (2015) TAM receptor signaling in immune homeostasis. Annu Rev Immunol 33:355-391. https://doi.org/10.1146/annurev-immunol-03241 4-112103

21. Lu Q, Lemke G (2001) Homeostatic regulation of the immune system by receptor tyrosine kinases of the Tyro 3 family. Science 293(5528):306-311. https://doi.org/10.1126/science.1061663

22. Seitz HM, Camenisch TD, Lemke G, Earp HS, Matsushima GK (2007) Macrophages and dendritic cells use different Axl/ Mertk/Tyro3 receptors in clearance of apoptotic cells. J Immunol 178(9):5635-5642. https://doi.org/10.4049/jimmunol.178.9.5635

23. Zagorska A, Traves PG, Lew ED, Dransfield I, Lemke G (2014) Diversification of TAM receptor tyrosine kinase function. Nat Immunol 15(10):920-928. https://doi.org/10.1038/ni.2986

24. Caraux A, Lu Q, Fernandez N, Riou S, Di Santo JP, Raulet DH, Lemke G, Roth C (2006) Natural killer cell differentiation driven by Tyro3 receptor tyrosine kinases. Nat Immunol 7(7):747-754. https://doi.org/10.1038/ni1353

25. Park IK, Giovenzana C, Hughes TL, Yu J, Trotta R, Caligiuri MA (2009) The Axl/Gas6 pathway is required for optimal cytokine signaling during human natural killer cell development. Blood 
113(11):2470-2477. https://doi.org/10.1182/blood-2008-05157073

26. Paolino M, Choidas A, Wallner S, Pranjic B, Uribesalgo I, Loeser S, Jamieson AM, Langdon WY, Ikeda F, Fededa JP, Cronin SJ, Nitsch R, Schultz-Fademrecht C, Eickhoff J, Menninger S, Unger A, Torka R, Gruber T, Hinterleitner R, Baier G, Wolf D, Ullrich A, Klebl BM, Penninger JM (2014) The E3 ligase Cbl-b and TAM receptors regulate cancer metastasis via natural killer cells. Nature 507(7493):508-512. https://doi.org/10.1038/nature12998

27. Behrens EM, Gadue P, Gong SY, Garrett S, Stein PL, Cohen PL (2003) The mer receptor tyrosine kinase: expression and function suggest a role in innate immunity. Eur J Immunol 33(8):2160 2167. https://doi.org/10.1002/eji.200324076

28. Shao WH, Eisenberg RA, Cohen PL (2008) The Mer receptor tyrosine kinase is required for the loss of $\mathrm{B}$ cell tolerance in the chronic graft-versus-host disease model of systemic lupus erythematosus. J Immunol 180(11):7728-7735. https://doi.org/10.4049/ jimmunol.180.11.7728

29. Shao WH, Zhen Y, Finkelman FD, Cohen PL (2014) The Mertk receptor tyrosine kinase promotes $\mathrm{T}-\mathrm{B}$ interaction stimulated by IgD B-cell receptor cross-linking. J Autoimmun 53:78-84. https ://doi.org/10.1016/j.jaut.2014.03.004

30. Ghosh AK, Secreto C, Boysen J, Sassoon T, Shanafelt TD, Mukhopadhyay D, Kay NE (2011) The novel receptor tyrosine kinase Axl is constitutively active in B-cell chronic lymphocytic leukemia and acts as a docking site of nonreceptor kinases: implications for therapy. Blood 117(6):1928-1937. https://doi.org/10.1182/ blood-2010-09-305649

31. Sinha S, Boysen J, Nelson M, Secreto C, Warner SL, Bearss DJ, Lesnick C, Shanafelt TD, Kay NE, Ghosh AK (2015) Targeted Axl inhibition primes chronic lymphocytic leukemia B cells to apoptosis and shows synergistic/additive effects in combination with BTK inhibitors. Clin Cancer Res 21(9):2115-2126. https:// doi.org/10.1158/1078-0432.CCR-14-1892

32. Cosemans JM, Van Kruchten R, Olieslagers S, Schurgers LJ, Verheyen FK, Munnix IC, Waltenberger J, Angelillo-Scherrer A, Hoylaerts MF, Carmeliet P, Heemskerk JW (2010) Potentiating role of Gas6 and Tyro3, Axl and Mer (TAM) receptors in human and murine platelet activation and thrombus stabilization. J Thromb Haemost 8(8):1797-1808. https://doi.org/10.111 $1 /$ j.1538-7836.2010.03935.x

33. Wang H, Chen S, Chen Y, Wang H, Wu H, Tang H, Xiong W, Ma J, Ge Y, Lu Q, Han D (2007) The role of Tyro 3 subfamily receptors in the regulation of hemostasis and megakaryocytopoiesis. Haematologica 92(5):643-650

34. Branchford BR, Stalker TJ, Law L, Acevedo G, Sather S, Brzezinski C, Wilson KM, Minson K, Lee-Sherick AB, Davizon-Castillo P, Ng C, Zhang W, Neeves KB, Lentz SR, Wang X, Frye SV, Shelton Earp H 3rd, DeRyckere D, Brass LF, Graham DK, Di Paola JA (2018) The small-molecule MERTK inhibitor UNC2025 decreases platelet activation and prevents thrombosis. J Thromb Haemost 16(2):352-363. https://doi.org/10.1111/jth.13875

35. Smiley ST, Boyer SN, Heeb MJ, Griffin JH, Grusby MJ (1997) Protein $S$ is inducible by interleukin 4 in $T$ cells and inhibits lymphoid cell procoagulant activity. Proc Natl Acad Sci USA 94(21):11484-11489. https://doi.org/10.1073/pnas.94.21.11484

36. Carrera Silva EA, Chan PY, Joannas L, Errasti AE, Gagliani N, Bosurgi L, Jabbour M, Perry A, Smith-Chakmakova F, Mucida D, Cheroutre H, Burstyn-Cohen T, Leighton JA, Lemke G, Ghosh S, Rothlin CV (2013) T cell-derived protein S engages TAM receptor signaling in dendritic cells to control the magnitude of the immune response. Immunity 39(1):160-170. https://doi. org/10.1016/j.immuni.2013.06.010

37. Chan PY, Carrera Silva EA, De Kouchkovsky D, Joannas LD, Hao L, Hu D, Huntsman S, Eng C, Licona-Limon P, Weinstein JS, Herbert DR, Craft JE, Flavell RA, Repetto S, Correale J, Burchard
EG, Torgerson DG, Ghosh S, Rothlin CV (2016) The TAM family receptor tyrosine kinase TYRO3 is a negative regulator of type 2 immunity. Science 352(6281):99-103. https://doi.org/10.1126/ science.aaf 1358

38. Peeters MJW, Dulkeviciute D, Draghi A, Ritter C, Rahbech A, Skadborg SK, Seremet T, Carnaz Simoes AM, Martinenaite E, Halldorsdottir HR, Andersen MH, Holmen Olofsson G, Svane IM, Rasmussen LJ, Met O, Becker JC, Donia M, Desler C, Thor Straten P (2019) MERTK acts as a costimulatory receptor on human CD8+ T cells. Cancer Immunol Res. https://doi. org/10.1158/2326-6066.CIR-18-0841

39. Hilliard BA, Zizzo G, Ulas M, Linan MK, Schreiter J, Cohen PL (2014) Increased expression of Mer tyrosine kinase in circulating dendritic cells and monocytes of lupus patients: correlations with plasma interferon activity and steroid therapy. Arthritis Res Ther 16(2):R76. https://doi.org/10.1186/ar4517

40. Cabezon R, Carrera-Silva EA, Florez-Grau G, Errasti AE, Calderon-Gomez E, Lozano JJ, Espana C, Ricart E, Panes J, Rothlin $\mathrm{CV}$, Benitez-Ribas D (2015) MERTK as negative regulator of human T cell activation. J Leukoc Biol 97(4):751-760. https:// doi.org/10.1189/jlb.3A0714-334R

41. Zhao GJ, Zheng JY, Bian JL, Chen LW, Dong N, Yu Y, Hong GL, Chandoo A, Yao YM, Lu ZQ (2017) Growth arrest-specific 6 enhances the suppressive function of CD4(+)CD25(+) regulatory $\mathrm{T}$ cells mainly through Axl receptor. Mediat Inflamm 2017:6848430. https://doi.org/10.1155/2017/6848430

42. Yokoyama Y, Lew ED, Seelige R, Tindall EA, Walsh C, Fagan PC, Lee JY, Nevarez R, Oh J, Tucker KD, Chen M, Diliberto A, Vaaler H, Smith KM, Albert A, Li G, Bui JD (2019) Immuno-oncological efficacy of RXDX-106, a novel TAM (TYRO3, AXL, MER) family small-molecule kinase inhibitor. Cancer Res 79(8):1996-2008. https://doi.org/10.1158/0008-5472.CAN-18-2022

43. Smiley ST, Stitt TN, Grusby MJ (1997) Cross-linking of protein $\mathrm{S}$ bound to lymphocytes promotes aggregation and inhibits proliferation. Cell Immunol 181(2):120-126. https://doi.org/10.1006/ cimm.1997.1210

44. Keating AK, Salzberg DB, Sather S, Liang X, Nickoloff S, Anwar A, Deryckere D, Hill K, Joung D, Sawczyn KK, Park J, CurranEverett D, McGavran L, Meltesen L, Gore L, Johnson GL, Graham DK (2006) Lymphoblastic leukemia/lymphoma in mice overexpressing the Mer (MerTK) receptor tyrosine kinase. Oncogene 25(45):6092-6100. https://doi.org/10.1038/sj.onc.1209633

45. Lee-Sherick AB, Jacobsen KM, Henry CJ, Huey MG, Parker RE, Page LS, Hill AA, Wang X, Frye SV, Earp HS, Jordan CT, DeRyckere D, Graham DK (2018) MERTK inhibition alters the PD-1 axis and promotes anti-leukemia immunity. JCI Insight. https:// doi.org/10.1172/jci.insight.97941

46. Simon S, Labarriere N (2017) PD-1 expression on tumor-specific T cells: friend or foe for immunotherapy? Oncoimmunology 7(1):e1364828. https://doi.org/10.1080/2162402X.2017.1364828

47. Akalu YT, Rothlin CV, Ghosh S (2017) TAM receptor tyrosine kinases as emerging targets of innate immune checkpoint blockade for cancer therapy. Immunol Rev 276(1):165-177. https://doi. org/10.1111/imr.12522

48. Bosurgi L, Bernink JH, Delgado Cuevas V, Gagliani N, Joannas L, Schmid ET, Booth CJ, Ghosh S, Rothlin CV (2013) Paradoxical role of the proto-oncogene Axl and Mer receptor tyrosine kinases in colon cancer. Proc Natl Acad Sci USA 110(32):13091-13096. https://doi.org/10.1073/pnas.1302507110

49. Li Q, Lu Q, Lu H, Tian S, Lu Q (2013) Systemic autoimmunity in TAM triple knockout mice causes inflammatory brain damage and cell death. PLoS One 8(6):e64812. https://doi.org/10.1371/ journal.pone. 0064812

Publisher's Note Springer Nature remains neutral with regard to jurisdictional claims in published maps and institutional affiliations. 